\title{
Disparitas Putusan Mengenai Persamaan Pada Pokoknya Pada Merek Predator (Studi Putusan Nomor 1146 K/Pdt.Sus-Hki/2020)
}

\author{
Muhammad Ali Masnun \\ Fakultas Ilmu Sosial dan Hukum, Universitas Negeri Surabaya, Surabaya, Indonesia \\ E-mail: alimasnun@unesa.ac.id
}

\begin{tabular}{l}
\multicolumn{1}{c}{ Dikirim: 01/05/2021 } \\
\hline Info Artikel \\
\hline Keywords: \\
Trademark; Similarity \\
in appearance; \\
Predator. \\
\\
Kata Kunci: \\
Merek; Persamaan \\
pada Pokoknya; \\
Predato.
\end{tabular}

\begin{tabular}{l} 
Direvisi: 23/10/2021 Dipublikasi: 31/12/2021 \\
\hline Abstract \\
The cases of trademark infringement on substantial similarity still relatively \\
common in Indonesia. This article aims to analyze the basis for the judge's \\
consideration in the decision Number $1146 \mathrm{~K} / \mathrm{Pdt}$. Sus-HKI / 2020. This is \\
based on the disparity of Decision Number $69 /$ Pdt. Sus / Mark / 2019 / PN \\
with Decision Number $1146 \mathrm{~K} / \mathrm{Pdt}$ Sus-HKI / 2020. This research uses \\
doctrinal research using statute, case, and conceptual approaches. The \\
results showed that the judges' basic considerations were not in accordance \\
with regulations and several legal concepts. First, that the trademark \\
protection system based on territorial territory and the first to file system \\
principle should not be used as a basis for consideration. Second, that the \\
two brands are basically similar because of the similarities in the dominant \\
element and the similarity in sound or speech with the addition of the same \\
class of goods. Third, the word "predator" cannot be categorized as a \\
generic word, because the word predator has been added with a logo as a \\
condition for a research, excluding generic brands. As a recommendation \\
in deciding this matter, regarding the existence of bad faith, due to bad faith, \\
a cancellation of a registered mark can be submitted indefinitely.
\end{tabular}

\section{Abstrak} terjadi di Indonesia. Artikel ini bertujuan untuk menganalisis dasar pertimbangan hakim pada putusan Nomor 1146 K/Pdt.Sus-HKI/2020. Hal tersebut didasarkan adanya disparitas Putusan Nomor 69/Pdt.Sus/Merek/2019/PN dengan Putusan Nomor 1146 K/Pdt.Sus$\mathrm{HKI} / 2020$. Penelitian menggunakan penelitian doktrinal dengan menggunakan pendekatan perundang-undangan, kasus, dan konseptual. Hasil penelitian menunjukkan bahwa dasar pertimbangan hakim belum sesuai dengan regulasi dan beberapa konsep hukum. Pertama, bahwa sistem pelindungan merek berdasarkan wilayah territorial dan prinsip first to file system patutnya tidak dijadikan sebagai dasar pertimbangan. Kedua, bahwa kedua merek tersebut memiliki persamaan pada pokoknya karena adanya persamaan pada unsur yang dominan dan persamaan bunyi atau ucapan dengan ditambah kelas barang yang sama. Ketiga, kata "predator" belum dapat dikategorikan sebagai kata generik, karena kata predator telah ditambah dengan logo sebagai syarat sebuah meret tidak termasuk merek generic. Sebagai rekomendasi dalam memutus hal tersebut adalah perihal adanya itikad tidak baik, karena adanya itikad tidak baik dapat diajukan 


\section{A. PENDAHULUAN}

Globalisasi telah memengaruhi berbagai bidang kehidupan, baik bidang ekonomi, sosial, maupun budaya. Bidang ekonomi meliputi kegiatan ekonomi yang dilakukan oleh para pelaku ekonomi (pelaku usaha) mulai produksi hingga produksi. Konsekuensinya kegiatan ekonomi pada era globalisasi perlu dituntut untuk dilakukannya berbagai inovasi secara berkelanjutan. Hal tersebut sangat beralasan, karena persaingan ekonomi pada era globalisasi sudah lintas batas negara. Produk dari dalam negeri dapat diekspor ke negara lain, begitu pula sebaliknya produk-produk yang berasal dari luar negeri juga sangat terbuka dan dapat membanjiri produk dalam negeri.

Pelaku ekonomi (pelaku usaha) perlu memperhatikan berbagai aspek agar eksistensinya terus terjaga. Salah satu aspek penting yang perlu diperhatikan adalah perihal pelindungan merek dagang. Hal tersebut sangat beralasan, mengingat merek memiliki fungsi untuk membedakan barang atau produksi satu perusahaan dengan barang atau jasa produksi perusahaan lain yang sejenis, artinya merek sebagai tanda pengenal atas barang dan/atau jasa yang bersangkutan ${ }^{1}$. Selain itu merek memegang peranan penting bagi kelangsungan dan peningkatan transaksi barang dan jasa dalam perdagangan maupuan investasi ${ }^{2}$.

Merek sebagai bentuk indentitas tambahan dari suatu produk yang tidak hanya membedakan dari produk pesaing, tetapi juga bentuk janji dari produsen atau kontrak kepercayaan dari produsen kepada konseumen dengan menjamin konsistensi bahwa sebuah produk akan selalu dapat menyampaikan nilai yang diharapkan konsumen dari sebuah produk ${ }^{3}$. Kecenderungan konsumen untuk membeli barang ditentukan melalui merek, karena kualitas dari barang dianggap melekat dengan merek tersebut. Merek menjadi indikasi yang memberikan reputasi, kualitas, tolok ukur bagi pembeli ${ }^{4}$. Hal senada diungkapkan Suyud Margono bahwa merek menggambarkan jaminan kepribadian (individuality) dan reputasi barang dan jasa hasil produksinya pada saat diperdagangkan ${ }^{5}$.

Memperhatikan urgensi pelindungan merek, seharusnya para pelaku ekonomi (pelaku usaha) yang memiliki kesadaran bagaimana merek tidak hanya sesuatu (label) yang ditempel begitu saja, melainkan juga sebagai suatu bentuk jaminan hukum terhadap merek agar diperlakukan sesuai dengan aturan yang berlaku ${ }^{6}$. Faktanya, bahwa berdasarkan beberapa kasus pada sektor hak kekayaan intelektual (HKI), merek selalu menempati posisi paling atas (paling banyak) dari sisi kuantitas apabila dibandingkan jenis HKI lain. Data tersebut dapat dilihat pada Grafik 1 di bawah ini:

1 Margono, S. (2010). Aspek Hukum Komersialisasi Aset Intelektual. Bandung: Nuansa Aulia.

2 Labetubun, M. A. H., Pariela, M. V. G. (2020). Controlling of Imported or Exported Goods Related to Brand Protection By Customs, UNTAG Law Review, 4(1), 20-33, https://doi.org/10.36356/ulrev.v4i1.1522.

3 Pane, O. B. M., \& Rini, E. S. (2011). Pengaruh Brand Equity Flash Disk Merek KingstonTerhadap Keputusan Pembelian Pada Mahasiswa Amik Mbp Medan. Jurnal Ekonom, 14(3), 115-126.

4 Indra, I., \& Andini, P. (2021, April). Pendampingan Pendaftaran Merek Dagang Gold Hill Di Direktorat Jenderal Kekayaan Intelektual. In ConCEPt-Conference on Community Engagement Project (Vol. 1, No. 1, pp. 418-424).

5 Margono, S., \& Hadi, L. (2002). Pembaharuan Perlindungan Hukum Merek. Jakarat: Novindo Pustaka Mandiri.

6 Hidayati, N. (2011). Perlindungan hukum pada Merek yang Terdaftar. Ragam Jurnal Pengembangan Humaniora, 11(3), 174-181.

$$
\text { 464|SASI Vo1. } 27 \text { No.4, Oktober - Desember } 2021
$$




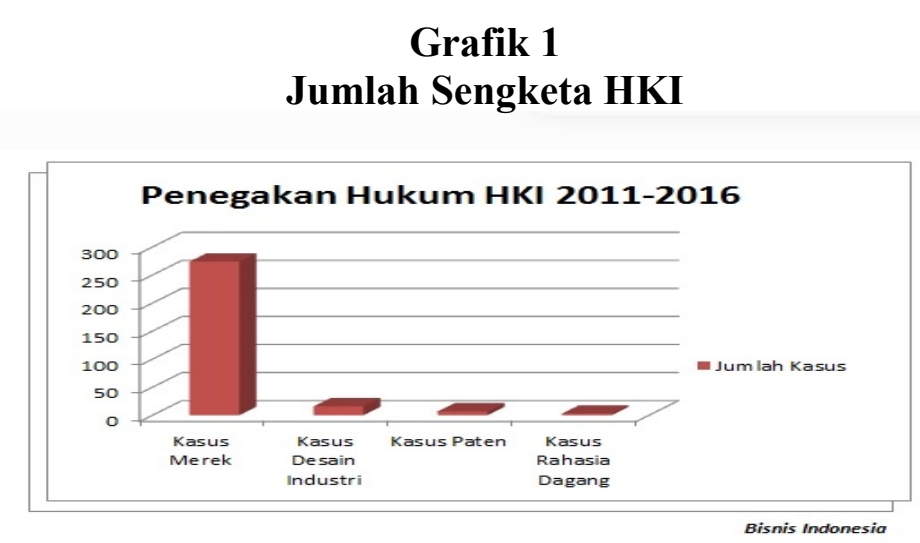

Berdasarkan Grafik.1 tampak bahwa kasus pelanggaran merek berada yang paling tinggi dibandingkan kasus yang lain. Artinya bahwa tidak menutup kemungkinan jumlah tersebut terus mengalami kenaikan dari tahun ke tahun karena kurangnya kesadaran para pelaku usaha untuk memberika pelindungan atas merek yang dimilikinya. Secara umum bahwa kasus pelanggaran merek yang marak terjadi adalah perihal persamaan pada pokoknya, persamaan pada keseluruhan, ataupun itikad tidak baik. Contoh kasus-kasus persamaan pada pokoknya ataupun keseluruhan di Indonesia dapat dilihat pada tabel 1 di bawah ini:

\section{Tabel 1 \\ Kasus Sengketa Merek}

\begin{tabular}{cll}
\hline No & \multicolumn{1}{c}{ Kasus } & \multicolumn{1}{c}{ Perihal } \\
\hline 1 & Gudang Garam & Persamaan pada pokoknya dan itikad tidak baik \\
\hline 2 & Pierre Cardin & Persamaan pada pokoknya dan merek terkenal \\
\hline 3 & Ikea & Persamaan pada pokoknya dan merek terkenal \\
\hline 4 & Superman & Merek terkenal dan itikad tidak baik \\
\hline 5 & Geprek Bensu & Persamaan pada pokoknya \\
\hline 6 & Air Mineral Crystalline & Persamaan pada pokoknya dan itikad tidak baik \\
\hline 7 & Hakubaku & Persamaan pada pokoknya dan itikad tidak baik \\
\hline 8 & Timberland & Persamaan pada pokokny dan merek terkenal \\
\hline 9 & Formula Strong & Persamaan pada pokoknya \\
\hline 10 & Predator & Persamaan pada pokoknya \\
\hline
\end{tabular}

Sumber: dari berbagi sumber, diolah

Kasus yang baru-baru ini cukup menjadi salah satu isu menarik untuk dikaji adalah perihal kasus Merek Predator yang melibatkan antara Wijen Chandra Tjia yang telah memiliki merek terdaftar lebih dahulu dengan PT Acer Incorporate yang sedang mengajukan merek Acer Predator dan ditolak permohonannya oleh Direktorat Jenderal Kekayaan Intelektual Kementerian Hukum dan Hak Asasi Manusia (DJKI Kemenkumham). Kronologi kasus tersebut berawal pada saat perusahaan yang berasal dari Taiwan, Acer Incorporated hendak mendaftarkan merek Acer Predator ke DJKI Kemenkumham pada tahun 2016. Namun demikian, permohonan tersebut ditolak oleh Kemenkumham pada tanggal 12 Februari 2019, dengan alasan merek tersebut memiliki persamaan pada pokoknya dengan merek yang telah terdaftar dan dimiliki oleh Wijen Chandra Tjia.

Penolakan pendaftaran tersebut, membuat pihak PT Acer Incorporate melakukan upaya hukum ke Komisi Banding Merek, meski hasil yang diperoleh akhirnya ditolak berdasarkan Putusan Komisi Banding Merek Nomor: 424/KBM/HKI/2019 tanggal 26 Juni 2019, dengan alasan yang sama yakni karena memiliki persamaan pada pokoknya dengan merek predator yang telah terdaftar dengan barang dengan nomor daftar IDM 0000482291. Pihak PT Acer

$$
\text { 465|S A I Vo1. } 27 \text { No.4, Oktober - Desember } 2021
$$


Incorporate yang masih merasa yakin dengan permohonan pendaftarannya terus berupaya untuk melakukan upaya hukum melalui jalur litigasi ke Pengadilan Niaga Jakarta Pusat. Upaya tersebut akhirnya kandas setelah majelis mengeluarkan menolak gugatan untuk seluruhnya berdasarkan Putusan Nomor 69/Pdt.Sus/Merek/2019/PN Niaga Jkt.Pst.

Kasasi ke Mahkamah Agung sebagai upaya hukum terakhir, akhirnya ditempuh oleh pihak PT Acer Incorporate. Bahwa dengan petitum yang sama, Putusan Nomor 1146 K/Pdt.Sus$\mathrm{HKI} / 2020$ telah mengabulkan permohonan penggugat keseluruhan. Berdasarkan putusan tersebut maka putusan tersebut telah mengesampingkan putusan sebelumnya baik di tingkat Komisi Banding Merek maupun putusan Pengadilan Niaga. Atas putusan tersebut juga, maka permohonan pendaftaran merek "Predator+logo" milik PT Acer Incorporated dikabulkan dan dapat melalui proses atau tahapan pendaftaran selanjutnya. Secara sederhana putusan-putusan tersebut tersajikan pada tabel 2:

Tabel 2

Putusan Terkait Kasus Merek Predator

\begin{tabular}{llll}
\hline No & \multicolumn{1}{c}{ Putusan } & \multicolumn{1}{c}{ Amar Putusan } \\
\hline 1 & Putusan Komisi Banding Merek Nomor: & $\begin{array}{l}\text { Menolak permohonan PT Acer } \\
\text { Incorporate keseluruhan }\end{array}$ \\
\hline 2 & $\begin{array}{l}\text { Putusan Nomor } \\
\text { Niaga Jkt.Pst. }\end{array}$ & $\begin{array}{l}\text { Menolak permohonan PT Acer } \\
\text { Incorporate keseluruhan }\end{array}$ \\
\hline 3 & Putusan Nomor 1146 K/Pdt.Sus-HKI/2020 & $\begin{array}{l}\text { Mengabulkan permohonan PT } \\
\text { Acer Incorporate keseluruhan }\end{array}$ \\
\hline
\end{tabular}

Sumber: Penulis

Mengacu pada tabel 2, maka bagaimana putusan pada tingkat komisi banding merek dan pengadilan niaga yang dapat dikategorikan sebagai judex factie (fakta hukum) sementara pada tingkat kasasi sebagai judex jurist (penerapan hukum) memiliki pandangan yang berbeda menafsirkan Pasal 21 ayat (1) Undang-Undang Merek dan Indikasi Geografis (UU Merek) berkaitan dengan persamaan pada pokoknya. Berdasarkan putusan tersebut maka ketentuan Pasal 21 ayat (1) dapat dikategorikan sebagai norma yang masih kabur (vaguenorm), oleh karena itu perlu norma yang jelas agar kasus-kasus sejenis pada masa sekarang maupun yang akan datang dapat diantisipasi dan tidak terulang kembali.

Artikel ini bertujuan untuk menganalisis dasar pertimbangan hakim pada putusan Nomor $1146 \mathrm{~K} / \mathrm{Pdt}$. Sus-HKI/2020 dan menganalisis ketentuan merek yang memiliki persamaan pada pokoknya. Interpretasi menjadi kunci penting dalam pemaknaan sebuah norma agar tidak terjadi kesimpangsiuran sehingga kepastian hukum menjadi barang penting untuk hadir sebagai nilai yang penting, disamping keadilan dan kemanfaatan. Interpretasi (penafsiran) merupakan bagian dari metode penemuan hukum (rechtvinding) yang kalau menurut Sudikno Mertokusumo dimaknai sebagai proses pembentukan hukum yang dilakukan oleh subyek atau pelaku penemuan hukum dengan cara penerapan regulasi terhadap peristiwa atas dasar kaidah yang dibenarkan menurut ilmu hukum ${ }^{7}$.

Riset sejenis perihal dengan persamaan pada pokoknya telah dilakukakan oleh beberapa peneliti sebelumnya. Evelyn Larissa telah menganalisis pelindungan hukum bagi konsumen apabila keliru memilih produk dikarenakan memiliki persamaan penyebutan dan pengucapan ${ }^{8}$ dengan melakukan studi kasus Microside dan Mikrozid. Riset tersebut merupakan irisan antara bidang pelindungan konsumen dan hak kekayaan intelektual (merek) dengan isu adanya

Mertokusumo, S. (2007). Penemuan Hukum: Sebuah Pengantar. Yogyakarta: Liberty.

Wijaya, E. L. F. (2020). Perlindungan Hukum Konsumen Atas Kesamaan Bunyi Merek Terhadap Barang Yang Tidak Sejenis. JCH (Jurnal Cendekia Hukum), 5(2), 185-197.

$$
\text { 466|S A S Vol. } 27 \text { No.4, Oktober - Desember } 2021
$$


kekosongan atau belum diaturnya perihal pelindungan bagi konsumen untuk memenuhi hak atas kenyamanan, keselamatan, dan keamanan. Riset serupa mengenai persamaan pada pokoknya telah diteliti oleh Pingkan F. D. Kalalo dkk yang mengkaji perihal gugatan pemilik terdaftar terhadap pihak lain jika menggunakan merek yang memiliki persamaan pada pokoknya atau keseluruhannya ${ }^{9}$ dengan tanpa hak. Riset tersebut menitikberatkan bagaimana ganti rugi dan atau penghentian semua perbuatan yang berkaitan dengan penggunaan merek menjadi salah satu upaya hukum yang bisa dilakukan apabila menggunakan merek yang persamaan dengan tanpa hak. Riset sejenis dilakukan pula oleh Kennedy Wijaya dengan fokus kajian pada pelindungan hukum terhadap pemilik merek terkenal Pierre Cardin Perancis terhadap pendaftaran merek Pierre Cardin Indonesia yang diterima oleh DJKI ${ }^{10}$. Riset yang dilakukan juga menggunakan variabel merek yang memiliki persamaan pada pokoknya yang kemudian dihubungkan dengan posisi Merek Pierre Cardin sebagai salah satu merek terkenal yang memiliki beberapa privilege dibandingkan dengan merek biasa. Berdasarkan beberapa riset terdahulu, maka penelitian ini dapat dipandang memiliki sudut pandang (point of view) yang berbeda khususnya bagaimana menganalisis dasar pertimbangan hakim pada putusan Nomor 1146 K/Pdt.Sus-HKI/2020.

\section{B. METODE PENELITIAN}

Penelitian ini dapat dikategorikan sebagai metode penelitian hukum doktrinal atau juga disebut penelitian normatif yang acapkali hukum dikonsepkan sebagai apa yang tertulis dalam peraturan perundang-undangan (law in books) ${ }^{11}$. Pendekatan perundang-undangan dalam penelitian ini menggunakan beberapa regulasi, utamanya Undang-Undang Merek. Pendekatan konseptual juga digunakan dengan mengelaborasi perihal merek dan persamaan pada pokoknya. Pendekatan kasus dengan menggunakan Putusan 1146 K/Pdt.Sus-HKI/2020 antara Acer Incorporated dengan Pemerintah Republik Indonesia (DJKI Kemenkumham) yang telah menolak permohonan merek pihak Acer Incorporated. Analisis menggunakan preskriptif yang ditunjang dengan buku, jurnal, yang berkaitan dengan topik yang dianalisis.

\section{PEMBAHASAN}

Pelindungan HKI di Indonesia merupakan konsekuensi atas penandatanganan General Agreement on Tarrifs and Trade (GATT) pada tahun 1994, yang kemudian melahirkan organisasi perdagangan dunia, World Trade Organization (WTO). Bentuk konkrit pelindungan tersebut adalah dengan memberikan instrumen hukum dalam bentuk peraturan perundangundangan HKI (industrial dan non industrial) dan melakukan penegakan hukum di bidang HKI.

Merek sebagai bagian dari rezim HKI industrial, melindungi kreativitas atas sebuah tanda yang digunakan dalam kegiatan perdagangan barang dan/atau jasa. Terminologi "tanda" sebagaimana dimaksud dalam khasanah HKI (hukum merek) mengalami dinamika dari waktu ke waktu. Pada awalnya, "tanda" hanya menggunakan "huruf" atau "angka" yang kemudian mengalami dinamika, khususnya sejak diberlakukannya ketentuan TRIPS-Plus menimbulkan akibat berupa perluasan merek yang tidak hanya meliputi visual (gambar, nama, kata, dan sebagainya) akan tetapi juga didasarkan pada suara, tekstur dan aroma ${ }^{12}$.

Dinamika yang berkembang sebagaimana dimaksud di atas, menunjukkan bagaimana

9 Kalalo, P. F. (2021). Gugatan Pemilik Merek Terdaftar Terhadap Pihak Lain Apabila Tanpa Hak Menggunakan Merek Barang Yang Mempunyai Persamaan Pada Pokoknya Atau Keseluruhannya. LEX PRIVATUM, 9(3), 119-129.

10 Wijaya, K., \& Neltje, J. (2020). Perlindungan Hukum Merek Terkenal (Kasus Sengketa Merek Pierre Cardin Perancis Vs Indonesia). Era Hukum-Jurnal Ilmiah Ilmu Hukum, 18(1), 192-216.

11 Amiruddin., \& Asikin, Z. (2016). Pengantar Metode Penelitian Hukum. Jakarta: Rajawali Pers.

12 Sanib, S. S. (2019). Ketentuan-ketentuan TRIPS-Plus dalam Kerangka Perjanjian Perdagangan Bebas. Halu Oleo Law Review, 3(1), 50-66.

$$
\text { 467|SASI Vo1. } 27 \text { No.4, Oktober - Desember } 2021
$$


merek yang digunakan sebagai salah satu identitas sebuah produk benar dirasa penting untuk dilindungi. Hal ini selaras dengan apa yang dikemukakan Simamora bahwa merek dapat memberikan perlindungan hukum melalui hak eksklusif yang diberikan oleh negara ${ }^{13}$.

Bahwa pelindungan merek menjadi sebuah hak atas merek (lahir hak eksklusif) tidak serta merta secara otomatis diberikan, melainkan harus didaftarkan. Hal ini disebabkan bahwa sistem pelindungan merek dalam konsep HKI akan diberikan setelah didaftarkan (first to file system) atau lazim disebut sistem konstitutif ${ }^{14}$. Perlindungan merek sangat penting, karena merek sebagai tanda pengenal yang menunjukkan asal barang dan jasa, sekaligus menghubungkan barang dan jasa yang bersangkutan dengan produsennya ${ }^{15}$, untuk itu maka kepastian hukum hak atas merek adalah hasil dari proses pendaftaran suatu merek untuk mendapatkan perlindungan hukum yang dapat dibuktikan dengan sertifikat Merek. ${ }^{16}$

Proses pendaftaran ke Direktorat Jenderal Kekayaan Intelektual (DJKI) Kementerian Hukum dan Hak Asasi Manusia inilah yang sering terjadi masalah. Kasus yang terjadi pada Acer Incorporate ini menjadi contoh bagaimana pendaftaran merek menjadi hal yang krusial. Hal tersebut menjadi penting bagaimana regulasi memberikan memberikan payung hukum yang jelas, pasti, dan prediktabel.

Berdasarkan kasus yang terjadi pada merek predator yang diajukan oleh Acer Incorporated kemudian memperoleh penolakan dari DJKI menunjukkan bagaimana pengaturan perihal persamaan pada pokoknya relatif masih belum jelas. Hal lain yang mempertegas adalah bahwa hakim pada tingkat pengadilan niaga dan mahkamah agung pada tingkat kasasi memberikan pandangan yang berbeda untuk menilai batasan persamaan pada pokoknya.

Memperhatikan dasar pertimbangan (ratio decidendi) hakim dalam putusan tingkat kasasi terdiri beberapa hal antara lain ${ }^{17}$ :

a. Acer Incorporated telah mendaftar lebih dahulu di beberapa negara, dan predator milik pengggat telah didistribusikan di Indonesia sejak tahun 2008 ;

b. Kedua merek tersebut tidak memiliki persamaan pada pokoknya; dan

c. Kata "predator" dapat dikategorikan sebagai kata generik yang berarti pemangsa bukan ciptaan pemilik merek yang terdaftar lebih dahulu.

Berdasarkan dasar pertimbangan hakim di atas maka ada beberapa catatan yang perlu dikritisi. Pertama, perihal Acer Incorporated telah mendaftar lebih dahulu di beberapa negara pada dasarnya tidak perlu dijadikan sebagai dasar pertimbangan hakim dalam memutus kasus tersebut. Hal ini karena pelindungan HKI (termasuk merek) sifatnya teritorial. Pendaftaran dan penegakan hukum harus dilakukan secara terpisah di masing-masing yurisdiksi bersangkutan ${ }^{18}$. Artinya bahwa pelindungan sebuah merek hanya terbatas pada wilayah (teritorial) dimana merek itu didaftarkan. Memperhatikan hal tersebut, ketika Acer Incorporated telah mendaftar di beberapa negara lain tidak berarti kemudian secara otomatis juga dilindungi di Indonesia.

Ketentuan tersebut pada dasarnya dapat disimpangi apabila merek milik Acer

13 Simamora, B. (2001). Memenangkan Pasar Dengan Pemasaran Efektif Dan Profitabel. Jakarta: Gramedia Pustaka Utama.

14 Masnun, M. A. (2019). Reorientasi Pengaturan Pemberdayaan Hukum Usaha Mikro Kecil Menengah Melalui Hak Atas Merek Kolektif. Jurnal Wawasan Yuridika, 3(2), 217-234.

15 Betlehn, A., \& Samosir, P. O. (2018). Upaya Perlindungan Hukum Terhadap Merek Industri UMKM Di Indonesia. Law and Justice, 3(1), 1-11.

16 Labetubun, M. A. H. (2017). "The Legal Review of The Rights of Foreign Brands Onweaknesses of First To Fole Registration Principles In Indonesia," in International Conference: Intellectual Property and Potential Resources for Public Welfare (Mataram: Faculty of Law, University of Mataram in Cooperation with Association of Intellectual Property Lecturer of Indonesia), 213-27.

17 Mahkamah Agung. (2020). "Salinan Putusan 1146 K/Pdt.Sus-HKI/2020"

18 Nofli. (2020). Modul Kekayaan Intelektual Lanjutan Bidang Merek Dan Indikasi Geografis. Jakarta: Kementerian Hukum dan Hak Asasi Manusia Direktorat Jenderal Kekayaan Intelektual.

$$
\text { 468|S A S Vol. } 27 \text { No.4, Oktober - Desember } 2021
$$


Incorporated telah dapat dikategorikan sebagai merek terkenal (wellknown mark). Meski Predator milik Acer Incorporated tidak terdaftar (belum terdaftar) di Indonesia, maka DJKI Kemenkumham sudah sepatutnya menolak permohonan dari pihak lain yang ingin mengajukan permohonan merek sejenis. OK Saidin mengungkapkan bahwa pengertian merek sejenis dapat dimaknai sebagai barang-barang atau jasa-jasa lain yang dianggap segolongan atau sekelas ${ }^{19}$. Faktanya, meskipun predator yang dimiliki oleh Acer Incorporated telah terdaftar di beberapa negara belum dapat dikategorikan sebagai merek terkenal.

Tolok ukur sebuah merek dapat dikategorikan sebagai merek terkenal dapat mengacu pada penjelasan Pasal 21 ayat (1) UU Merek, antara lain tingkat pengetahuan umum masyarakat mengenai merek predator, reputasi Merek tersebut yang diperoleh karena promosi yang gencar dan besar-besaran, investasi di beberapa negara di dunia yang dilakukan oleh pemiliknya, dan disertai bukti pendaftaran Merek dimaksud di beberapa negara.

Selain pendaftaran yang dibatasi wilayah territorial, pendaftaran merek menganut prinsip first to file system (sistem konstitutif) atau dikenal dengan doktrin prior in filing (presumption of ownership). Maknanya bahwa pelindungan hak eksklusif atas sebuah merek diberikan bagi predator yang telah mendaftar lebih dahulu (Wijen Chandra). Acer Incorporated yang baru mendaftaran belakangan setelah merek predator milik Wijen Chandra, tidak dapat kemudian dapat diterima. Kecuali pada saat pendaftaran pertama kali Acer Incorporated menggunakan Hak Prioritas atau rezim sekarang menggunakan Madrid Protokol.

Hak prioritas adalah hak yang diberikan untuk diberikan tanggal pendaftaran pertama dari negara asal pertama kali pengajuan prioritas di negara tujuan yang juga anggota yang tergabung dalam Kovensi Paris sebagaimana diatur pada Pasal 9 dan Pasal 10 UU Merek. Sangat mungkin sekali apabila Acer Incorporated memiliki kesadaran penuh pentingnya sebuah pelindungan merek, sejak awal menggunakan hak prioritas namun faktanya tidak demikian. Sedangkan untuk pendaftaran Sistem Madrid Protokol yang telah difasilitasi setelah diberlakukan pada UU Merek. Sistem Madrid Protokol dimungkinkan para pemohon tidak harus daftar langsung ke negara yang dituju, melainkan cukup di negara tersebut yang kemudian menggunakan sistem tersebut.

Hal lain yang patut dipertimbangkan perihal pengajuan pendaftaran merek predator dari pihak Acer Incorporated adalah mengenai kelas barang yang sama yakni Kelas 9 untuk jenis barang: "Perangkat keras komputer, komputer, komputer desktop, komputer notebook, tablet PC, periferal komputer yaitu monitor, headset, speaker, tas komputer, cover komputer, kabel komputer, konverter komputer, pena stylus komputer, mouse komputer, papan tombol (keyboard) komputer". Pengajuan pendaftaran dengan merek dan kelas yang berbeda sangat mungkin sekali untuk dapat dipertimbangkan sebagaimana merek Baterai "ABC", Kecap "ABC", ataupun Kopi ABC yang masing-masing memiliki kelas barang yang berbeda.

Dasar pertimbangan kedua yang diberikan oleh hakim adalah perihal tidak adanya persamaan pada pokoknya pada kedua label merek tersebut. Penentuan sebuah merek apakah mempunyai persamaan pada pokoknya memang relatif lebih sulit apabila dibandingkan menentukan merek yang mempunyai persamaan pada keseluruhannya. Atas dasar hal itu diperlukan sebuah pemahaman yang komprehensif, kecermatan, kejelian dan ketelitian dalam memeriksa perkara tersebut.

Menariknya pada kasus tersebut, bahwa sebelum putusan $1146 \mathrm{~K} / \mathrm{Pdt}$.Sus-HKI/2020 menyatakan ada persamaan pada pokoknya pada kedua merek tersebut. Namun demikian Hakim pada tingkat kasasi berpandangan lain yang menyatakan kedua merek tersebut tidak memiliki kesamaan pada pokoknya. Perbandingan kedua merek tersebut tersaji pada gambar 1.

19 Saidin, OK. (2007). Aspek Hukum Hak Kekayaan Intelektual (Intellectual Property Rights). Jakarta: Rajagrafindo Persada.

$$
\text { 469|SASI Vol. } 27 \text { No.4, Oktober-Desember } 2021
$$




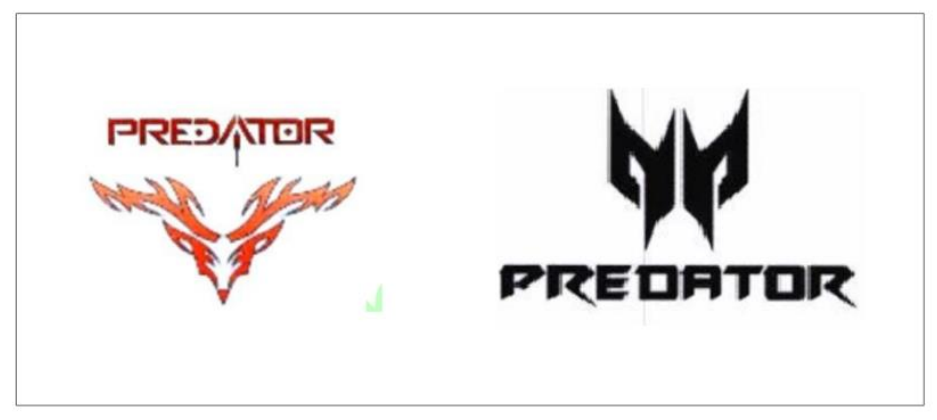

\section{Gambar 1 \\ Perbandingan Merek Predator}

Berdasarkan Gambar 1 di atas, label merek sebelah kiri Predator dengan di bawah logo warna merah milik Wijen Chandra dengan nomor pendaftaran IDM000482291 dengan tanggal pendaftaran 2 Juli 2015. Sementara label merek sebelah kanan merupakan milik Acer Predator dengan dominasi warna hitam dan tulisan berada di bawah yang telah diajukan permohonan pendaftarannya Merek "PREDATOR + Logo" dengan Agenda No. D002017047770 di Kelas 9.

Perihal ketentuan persamaan pada pokoknya, telah diatur pada Pasal 21 ayat (1) huruf a UU Merek. Pada dasarnya ketentuan tersebut memberikan pengaturan bagaimana sebuah merek ditolak apabila memiliki persamaan pada pokoknya atau keseluruhan dengan:

a) Merek terdaftar milik pihak lain atau dimohonkan lebih dahulu oleh pihak lain untuk barang dan/atau jasa sejenis;

b) Merek terkenal milik pihak lain untuk barang dan/atau jasa sejenis;

c) Merek terkenal milik pihak lain untuk barang dan/atau jasa tidak sejenis yang memenuhi persyaratan tertentu; atau

d) Indikasi Geografis terdaftar.

Untuk menemukan makna persamaan pada pokoknya setidaknya dapat menggunakan interpretasi. Bahwa interpretasi merupakan salah satu metode untuk menafsirkan terhadap teks perundang-undangan yang tidak jelas, agar perundang-undangan tersebut dapat diterapkan terhadap peristiwa konkrit tertentu ${ }^{20}$. Dari beberapa macam interpretasi sangat relevan terkait untuk memperjelas makna persamaan pada pokoknya dapat menggunakan interpretasi autentik atau resmi (authentieke atau officiele interpretatie). Interpretasi autentik merupakan penafsiran yang dilakukan berdasarkan pengertian yang ditentukan oleh pembentuk undang-undang dan yang biasanya diletakkan pada bagian penjelasan (memorie van toelichting).

Makna persamaan pada pokoknya apabila ditafsirkan dengan menggunakan interpretasi autentik maka dapat dimaknai sebagai "kemiripan yang disebabkan oleh adanya unsur yang dominan antara Merek yang satu dengan Merek yang lain sehingga menimbulkan kesan adanya persamaan, baik mengenai bentuk, cara penempatan, cara penulisan atau kombinasi antara unsur, maupun persamaan bunyi ucapan, yang terdapat dalam Merek tersebut".

Mengacu pada penjelasan UU Merek ada beberapa unsur yang dapat dijadikan sebagai tolok ukur persamaan pada pokoknya, antara lain: mirip, unsur dominan, menimbulkan kesan sama (bentuk, penempatan, penulisan, bunyi ucapan). Apabila diperhatikan secara seksama merek Acer Incorporate terdiri dari kata Predator dengan logo berwarna hitam, sedangkan merek milik Wijen Chandra terdiri dari kata Predator dengan logo berwarna merah. Sehingga secara tampilan visual tidak terkesan memiliki kemiripan di antara keduanya.

Perihal unsur yang dominan, sepintas kedua merek predator tersebut hanya mempunyai

20 Sutiyoso, B. (2015). Metode Penemuan Hukum (Upaya Mewujudkan Hukum Yang Pasti Dan Berkeadilan). Yogyakarta: UII Press.

470|SASI Vol. 27 No.4, Oktober - Desember 2021 
persamaan dari segi bunyi ucapan saja yaitu kata "Predator", meski demikian "Predator" menurut pandangan penulis merupakan unsur dominan, yang sangat mungkin sekali menimbulkan kekeliruan. Pada merek yang demikian, membuat konsumen beranggapan bahwa merek tersebut terasosiasi atau berasal dari satu produksi yang sama dengan merek yang diserupainya $^{21}$. Hal tersebut selaras dengan Yurisprudensi MA Nomor 2933 K/SIP/1982 yang menjelaskan bahwa "kriteria sejenis yaitu apabila mempunyai persamaan pada asal, sifat, dan tujuan pemakaiannya". Terlebih permohonan pendaftaran baru memiliki kelas barang yang sama, sehingga produk yang akan dijual tentu produk yang sama barangnya.

Perihal menimbulkan kesan yang sama maka dapat diuraikan satu persatu antara lain: persamaan bentuk yakni persamaan rupa atau persamaan penampilan dari suatu merek dengan merek yang lain. Sebuah merek yang memiliki kesamaan kata atau makna dapat dikategorikan sebagai merek yang memiliki persamaan bentuk. Selain itu, mereka yang dapat dikategorikan sebagai merek yang memiliki kesamaan bentuk adalah merek yang hanya menambahkan kata atau huruf dalam sebuah merek ${ }^{22}$. Apabila mengacu pada penjelasan tersebut, maka Predator milik Acer Incorporate memiliki kesamaan kata yakni "predator" tanpa ada penambahan kata melainkan hanya menggunakan logo yang berbeda.

Persamaan cara penempatan adalah persamaan letak atau posisi dari suatu merek dengan merek yang lainnya. Persamaan cara penempatan ini dapat berupa penempatan logo dalam suatu merek atau penempatan tulisan maupun nama dari sebuah merek ${ }^{23}$. Memperhatikan penjelasan tersebut maka berdasarkan cara penempatan kedua merek tersebut relatif berbeda tajam yakni penempatan tulisan predator ada yang di bawah dan di atas logo dengan warna dominasi yang berbeda pula.

Persamaan cara penulisan adalah persamaan cara tulisan sebuah merek mirip dengan merek yang lainnya. Persamaan cara penulisan ini sering kali terjadi pada merek yang bergerak di bidang yang sama, yang memiliki merek yang mirip dan konsumen yang sama. Umumnya, persamaan cara penulisan ini memiliki merek yang hampir sama tulisannya maupun merek yang hampir sama bunyinya ${ }^{24}$. Mencermati kedua merek tersebut, maka memiliki jenis font yang berbeda namun demikian kedua merek tersebut memiliki kelas barang yang sama sehingga memiliki konsumen yang sama dan sangat mungkin membuat bingung konsumen.

Persamaan ucapan atau persamaan bunyi adalah persamaan yang timbul dari pendengaran apabila sebuah merek diucapkan. Persamaan ucapan ini memiliki ciri-ciri yaitu membingungkan ketika didengar. Penggunaan kata "Predator" pada kedua merek tersebut tampak jelas orang mengatakan pasti sama dan ada kemungkinan konsumen bingung.

Memperhatikan formulasi daripada Pasal 21 ayat (1) yang menggunakan ketentuan alternatif, maka tidak mengharuskan semua unsur tersebut terpenuhi melainkan cukup salah satu saja terpenuhi maka persamaan pada pokoknya dapat dianggap memenuhi khususnya terkait dengan unsur yang dominan dan persamaan bunyi atau ucapan.

Dasar pertimbangan hakim yang ketiga mengenai "predator" yang dikategorikan sebagai kata generik atau public domain, yang dapat diartikan "pemangsa". Istilah generik adalah kata umum atau istilah umum, yang sering ditemukan di dalam kamus, untuk mengidentifikasi produk-produk dan jasa-jasa dan tidak spesifik untuk sumber tertentu. Black's Law Dictionary $^{25}$ memberikan definisi nama generik sebagai istilah yang menggambarkan sesuatu

21 Indriyanto, A., \& Yusnita, I. M. (2017). Aspek Hukum Pendaftaran Merek. Jakarta: Rajawali Press.

22 Christiangie, K., Santoso, B., \& Saptono, H. (2019). Pedoman Penentuan Persamaan Pada Pokoknya Oleh Lembaga Peradilan Di Indonesia (Studi Putusan Mahkamah Agung Nomor 409 K/Pdt. SusHKI/2015). Diponegoro Law Journal, 8(3), 2117-2130.

23 Ibid.

24 Ibid.

25 Black, H. C. (1999). Black's Law Dictionary: Definitions of the Terms and Phrases of American. Minnesota: West Group.

$$
\text { 471|SASI Vo1.27 No.4, Oktober-Desember } 2021
$$


secara umum tanpa perlu menunjukkan sumber atau penciptanya. Dengan demikian kata tersebut dapat dimaknai setiap orang dapat menggunakan tanpa harus izin. Hal ini selaras dengan Rahmi Jened yang mengatakan bahwa nama generik merujuk tes pemahaman konsumen atas suatu kata tertentu ${ }^{26}$.

Indonesia belum memiliki regulasi yang mengatur secara rinci mengenai merek generik ${ }^{27}$, ketentuan yang diatur dalam UU Merek hanya dua pasal yakni pada Pasal 20 dan Pasal 22. Pada Pasal 20 menekankan mengenai merek tidak dapat didaftar apabila merupakan nama umum dan/atau lambang milik umum. Nama umum sebagaimana dimaksud pada penjelasannya lebih memberikan contoh bagaimana merek "rumah makan" untuk restoran tidak diperkenankan, merek "warung kopi" untuk kafe.

Lebih lanjut ketentuan mengenai merek generik diatur pada Pasal 22 yang berbunyi sebagai berikut: "Terhadap Merek Terdaftar yang kemudian menjadi nama generik, setiap Orang dapat mengajukan Permohonan Merek dengan menggunakan nama generik dimaksud dengan tambahan kata lain sepanjang ada unsur pembeda."

Penjelasan mengenai hal tersebut tidak terdapat keterangan lebih lanjut mengenai sejauh mana suatu merek dapat dikategorikan sebagai nama yang mendeskripsikan suatu benda secara umum atau nama generik sehingga kurang praktis apabila pemilik merek ingin membuktikan bahwa merek miliknya sudah menjadi nama generik, pemilik harus meninjau dari instrumen hukum.

Berdasarkan uraian hal tersebut, apakah kemudian merek predator dapat dikategorikan sebagai merek generik sebagai dijadikan sebagai dasar pertimbangan hakim dalam putusan. Apabila mengacu pada ketentuan Pasal 20 UU Merek berikut dengan penjelasannya, maka kata "predator" tidak dapat memenuhi unsur Pasal 20 sehingga merek tersebut tidak memenuhi sebagai merek generik. Kata "predator" lebih memiliki makna pemangsa karena lebih pada kata serapan asing. Kalaupun kemudian kata "predator" dimaknai telah menjadi merek generik, maka untuk dapat memperoleh pelindungan merek maka perlu ada tambahan kata lain sebagaimana diatur pada Pasal 22 UU Merek Memperhatikan kata "predator" pada kedua merek tersebut telah ada tambahan berupa logo yang berbeda.

\section{P E N U T U P}

Dasar pertimbangan hakim dalam memutus dan mengabulkan permohonan Acer Incorporated belum sesuai dengan Undang-Undang Merek dan beberapa konsep hukum. Mencermati dasar pertimbangan hakim pertama, bahwa merek telah mendaftar lebih dahulu di beberapa negara, dan predator milik penggugat telah didistribusikan di Indonesia sejak tahun 2008, patutnya tidak digunakan karena sistem perlindungan merek berdasarkan wilayah territorial dan prinsip first to file system. Kedua, merek tersebut tidak memiliki persamaan pada pokoknya, merupakan hal yang perlu dicermati kembali karena adanya persamaan pada unsur yang dominan dan persamaan bunyi atau ucapan dengan ditambah kelas barang yang sama. Ketiga, kata "predator" dikategorikan sebagai kata generik yang berarti pemangsa bukan ciptaan pemilik merek yang terdaftar lebih dahulu, agak terlalu dipaksakan, karena kata predator telah ditambah dengan logo sebagai syarat sebuah meret tidak termasuk merek generic. Sebagai rekomendasi dalam memutus hal tersebut adalah perihal adanya itikad tidak baik, karena adanya itikad tidak baik dapat diajukan pembatalan merek terdaftar tanpa batas waktu.

26 Jened, R. (2015). Hukum Merek Dalam Era Global Dan Integrasi Ekonomi. Jakarta: Prenada Media Group.

27 Hutasuhut. P. (2018). Pelindungan Hukum Bagi Merek Terdaftar Yang Menjadi Nama Generik Ditinjau Dari Undang-Undang Nomor 20 Tahun 2016 (Skripsi: Universitas Padjajaran). 


\section{DAFTAR PUSTAKA}

\section{Jurnal}

[1] Betlehn, A., \& Samosir, P. O. (2018). Upaya Perlindungan Hukum Terhadap Merek Industri UMKM Di Indonesia. Law and Justice, 3(1), 1-11.

[2] Christiangie, K., Santoso, B., \& Saptono, H. (2019). Pedoman Penentuan Persamaan Pada Pokoknya Oleh Lembaga Peradilan Di Indonesia (Studi Putusan Mahkamah Agung Nomor 409 K/Pdt. Sus-HKI/2015). Diponegoro Law Journal, 8(3), 2117-2130.

[3] Hidayati, N. (2011). Perlindungan Hukum pada Merek yang Terdaftar. Ragam Jurnal Pengembangan Humaniora, 11(3), 174-181.

[4] Indra, I., \& Andini, P. (2021, April). Pendampingan Pendaftaran Merek Dagang Gold Hill Di Direktorat Jenderal Kekayaan Intelektual. In ConCEPt-Conference on Community Engagement Project (Vol. 1, No. 1, pp. 418-424).

[5] Kalalo, P. F. (2021). Gugatan Pemilik Merek Terdaftar Terhadap Pihak Lain Apabila Tanpa Hak Menggunakan Merek Barang Yang Mempunyai Persamaan Pada Pokoknya Atau Keseluruhannya. LEX PRIVATUM, 9(3), 119-129.

[6] Labetubun, M. A. H. (2017). "The Legal Review of The Rights of Foreign Brands Onweaknesses of First To Fole Registration Principles In Indonesia," in International Conference: Intellectual Property and Potential Resources for Public Welfare (Mataram: Faculty of Law, University of Mataram in Cooperation with Association of Intellectual Property Lecturer of Indonesia), 213-27.

[7] Labetubun, M. A. H., Pariela, M. V. G. (2020). Controlling of Imported or Exported Goods Related to Brand Protection By Customs, UNTAG Law Review, 4(1), 20-33, https://doi.org/10.36356/ulrev.v4i1.1522.

[8] Masnun, M. A. (2019). Reorientasi Pengaturan Pemberdayaan Hukum Usaha Mikro Kecil Menengah Melalui Hak Atas Merek Kolektif. Jurnal Wawasan Yuridika, 3(2), 217-234.

[9] Pane, O. B. M., \& Rini, E. S. (2011). Pengaruh Brand Equity Flash Disk Merek KingstonTerhadap Keputusan Pembelian Pada Mahasiswa Amik Mbp Medan. Jurnal Ekonom, 14(3), 115-126.

[10] Sanib, S. S. (2019). Ketentuan-ketentuan TRIPS-Plus dalam Kerangka Perjanjian Perdagangan Bebas. Halu Oleo Law Review, 3(1), 50-66.

[11] Wijaya, E. L. F. (2020). Perlindungan Hukum Konsumen Atas Kesamaan Bunyi Merek Terhadap Barang Yang Tidak Sejenis. JCH (Jurnal Cendekia Hukum), 5(2), 185-197.

[12] Wijaya, K., \& Neltje, J. (2020). Perlindungan Hukum Merek Terkenal (Kasus Sengketa Merek Pierre Cardin Perancis Vs Indonesia). Era Hukum-Jurnal Ilmiah Ilmu Hukum, 18(1), 192-216.

\section{Buku}

[13] Amiruddin., \& Asikin, Z. (2016). Pengantar Metode Penelitian Hukum. Jakarta: Rajawali Pers.

[14]Black, H. C. (1999). Black's Law Dictionary: Definitions of the Terms and Phrases of American. Minnesota: West Group.

[15] Indriyanto, A., \& Yusnita, I. M. (2017). Aspek Hukum Pendaftaran Merek. Jakarta: Rajawali Press.

[16]Jened, R. (2015). Hukum Merek Dalam Era Global Dan Integrasi Ekonomi. Jakarta: Prenada Media Group.

[17] Margono, S., \& Hadi, L. (2002). Pembaharuan Perlindungan Hukum Merek. Jakarat: Novindo Pustaka Mandiri..

[18] Margono, S. (2010). Aspek Hukum Komersialisasi Aset Intelektual. Bandung: Nuansa Aulia.

[19] Mertokusumo, S. (2007). Penemuan Hukum: Sebuah Pengantar. Yogyakarta: Liberty. 
[20] Nofli. (2020). Modul Kekayaan Intelektual Lanjutan Bidang Merek Dan Indikasi Geografis. Jakarta: Kementerian Hukum dan Hak Asasi Manusia Direktorat Jenderal Kekayaan Intelektual.

[21] Saidin, OK. (2007). Aspek Hukum Hak Kekayaan Intelektual (Intellectual Property Rights). Jakarta: Rajagrafindo Persada.

[22] Simamora, B. (2001). Memenangkan Pasar Dengan Pemasaran Efektif Dan Profitabel. Jakarta: Gramedia Pustaka Utama.

[23] Sutiyoso, B. (2015). Metode Penemuan Hukum (Upaya Mewujudkan Hukum Yang Pasti Dan Berkeadilan). Yogyakarta: UII Press.

\section{Online/World Wide Web, Skripsi dll}

[24]Hutasuhut. P. (2018). Pelindungan Hukum Bagi Merek Terdaftar Yang Menjadi Nama Generik Ditinjau Dari Undang-Undang Nomor 20 Tahun 2016 (Skripsi: Universitas Padjajaran).

[25] Mahkamah Agung. (2020). "Salinan Putusan 1146 K/Pdt.Sus-HKI/2020”. 